\title{
COMPOSITION, INTERNAL STRUCTURES, AND AN HYPOTHESIS OF FORMATION FOR DRUMLINS, WAUKESHA COUNTY, WISCONSIN, U.S.A.
}

\author{
By G. Richard Whittecar and David M. Mickelson \\ (Department of Geology and Geophysics, University of Wisconsin-Madison, Madison, \\ Wisconsin 53706, U.S.A.)
}

\begin{abstract}
Late Wisconsin-age drumlins west of Milwaukee are clustered atop uplands bounded by discrete scarps. Gravel operations within the uplands have exposed drumlin cores of undeformed till and outwash beds which are truncated at the sides of the drumlin. In a few areas, clastic dikes, faults, overturned bedding and shear folds disturb the original layering. The drumlin shapes are blanketed with a basal till I-3 $\mathrm{m}$ thick ("retreat" till) which truncates all internal structures. This till covering cannot be distinguished from the youngest truncated till ("advance" till).

Truncation of all of these structures shows that these drumlins are erosional forms carved from preexisting drift. Apparently, during erosion under compressive flow, some beds became un table and initiated large-scale movements of material into the drumlin from beneath the drumlin form. Failure and mobilization of the finer-grained beds may have been due to increased pore pressures, differing stages of dilatancy, or differing bulk densities. A growth relationship for drumlins may exist that is based upon the rates of material moving into the drumlin from below and rates of erosion of the drumlin form.
\end{abstract}

RÉsumÉ. Composition, structure interne, et hypothèse de formation des drümlins, Waukesha County, Wisconsin, U.S.A. Des drümlins datant de la fin du Wisconsin à l'ouest de Milwaukee sont groupés au-dessus de plateaux limités par des escarpements. Des recherches de gravier dans les plateaux ont mis à jour des coeurs de drümlins formés de dépôts morainiques non déformés et de lits lessivés qui sont coupés sur les bords du drümlin. En quelques zones, des cordons de matériaux clastiques, des interruptions des lits retournés et des plis de cisaillement perturbent l'empilement originel. Les formes des drümlins sont noyées dans une moraine de base de I à $3 \mathrm{~m}$ d'épaisseur (moraine de "retrait") qui découpe toutes les structures internes. Cette moraine de couverture ne peut être distinguée de la moraine découpée la plus récente (moraine d"“avancée").

Le découpage de toutes ces structures montre que ces drümlins sont des formes d'érosion taillées dans des apports préexistants. Apparemment, au cours de l'érosion sous des écoulements en compression, quelques lits devinrent instables et commencèrent à subir des mouvements sur une grande échelle vers le drümlin de matériaux issus d'en dessous de la forme du drümlin. La rupture et la mise en mouvement des lits aux grains plus fins peuvent avoir été dues à l'augmentation des pressions internes, à des différences de dilatation ou de densité apparente. Une loi de croissance pour les drümlins peut exister basée sur les vitesses d'entrainement des matériaux des niveaux inférieurs vers le drümlin ainsi que sur les vitesses d'érosion de forme drümlin.

Zusammenfassung. Zusammensetzung, innere Struktur und Bildungshypothese für Drumlins in Waukesha County, Wisconsin, U.S.A. Drumlins aus der späten Wisconsineiszeit westlich von Milwaukee häufen sich auf Hochflächen, die durch getrennte Böschungen begrenzt sind. Kiesentnahmen auf den Hochflächen haben Drumlinkerne aus ungestörtem Schutt und Schmelzwasserrinnen freigelegt, die an den Flanken der Drumlins enden. In ein paar Gebieten stören brüchige Dämme, Verwerfungen und Scherfalten die ursprüngliche Lagerung. Die Drumlinformen sind mit $1-3 \mathrm{~m}$ dicker Grundmoräne ("Rückzugsmoräne") bedeckt, die alle inneren Strukturen kappt. Diese Schutthülle lässt sich vom jüngsten gekappten Schutt ("Vorstossmoräne") nicht unterscheiden.

Die Kappung all dieser Strukturen zeigt, dass diese Drumlins Erosionsformen sind, die aus einer älteren Ablagerung herauspräpariert wurden. Während der Erosion unter kompressivem Fliessen wurden einige Rinnen sichtlich instabil und verursachten grossräumige Materialtransporte in die Drumlins von unten her. Verfall und Öffnung der feinerkörnigen Rinnen kann durch erhöhten Porendruck, verschiedene Stadien der Dehnung oder verschiedene Dichte hervorgerufen worden sein. Für Drumlins könnte ein Wachstumsgesetz bestehen, das auf der Geschwindigkeit des Massentransports in den Drumlin von unten und auf der Erosionsgeschwindigkeit der Drumlinform beruht.

\section{INTRODUCTION}

Drumlins have fascinated geomorphologists perhaps more than any other glacial landform. Their symmetry, spatial groupings, and the variability of their lengths, heights and materials have led to a variety of theories of drumlin formation. Early workers debated whether drumlins were products of deposition by the "plastering on" or lodgement of till around obstacles, or rather the result of incomplete subglacial erosion. More recent studies have concluded that both erosion and deposition were somehow involved in drumlin formation 
(see Muller, [ $\left.{ }^{{ }^{1}}{ }_{974}\right]$ ). However, the mechanisms of formation and the interplay between deposition and erosion have never been established. This paper contains an hypothesis of formation primarily based on erosional processes but also containing possible mechanisms for the "growth" of drumlins. Derived from excellent exposures of drumlin interiors within a modest sized drumlin field, this hypothesis has potential for explaining many features found in drumlins in other areas.

The Waukesha drumlin field, first mapped by Alden (1918), contains about $65^{\circ}$ drumlins and related streamlined features surrounding Waukesha, Wisconsin (Fig. I). Formed by ice advancing out of the Lake Michigan basin approximately 14500 years B.P. (Willman and

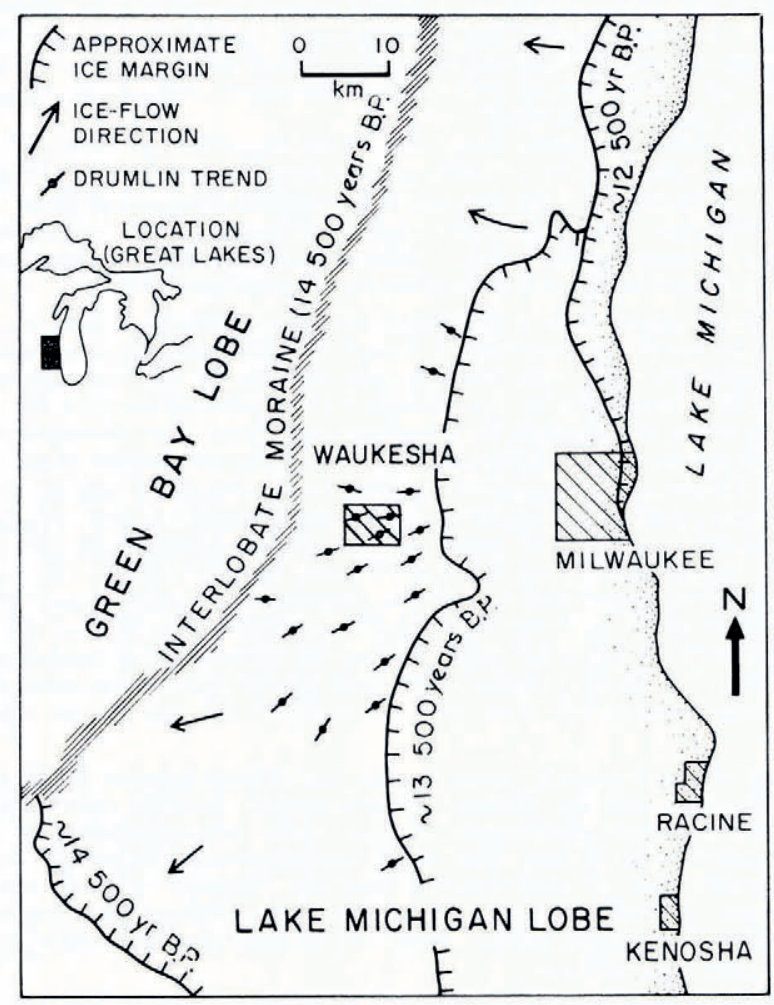

Fï. 1. Map of eastern Wisconsin showing the location of the Waukesha drumlin field relative to margins of the Green Bay and Lake Michigan lobes. Dates on limits of ice advances are only approximate and are not well documented ( from Alden, 1.918$)$.

Frye, 1970, p. 204), the drumlin field abuts the Kettle interlobate moraine on the west and is overlapped by a younger set of moraines to the east. Westward flow of the Lake Michigan lobe was impeded by the south-eastward flow of the neighboring Green Bay lobe and the gentle eastward dip of underlying Silurian dolomites (Martin, 1916).

This particular drumlin field was chosen for study because of its manageable size (approximately $\mathrm{I} 100 \mathrm{~km}^{2}$ ) and its numerous gravel operations. Seventeen drumlins are extensively exposed due to this mining. Although using mostly gravel pits as study sites biased data towards drumlins which contained considerable sand and gravel, well logs indicate that a large portion of the drumlins in this field are cored with thick gravel deposits. 
('HARACTERISTICS OF THE DRLMLIN FIELD

The Waukesha drumlin field is only a small part of the area covered by the Lake Michigan lobe which moved far south into Illinois (Willman and Frye, 1970). It lies north and cast of the Darien moraine and Kettle interlobate moraine which presumably were deposited at the time of drumlin formation (Alden, 1918). The width of the zone of drumlins behind the

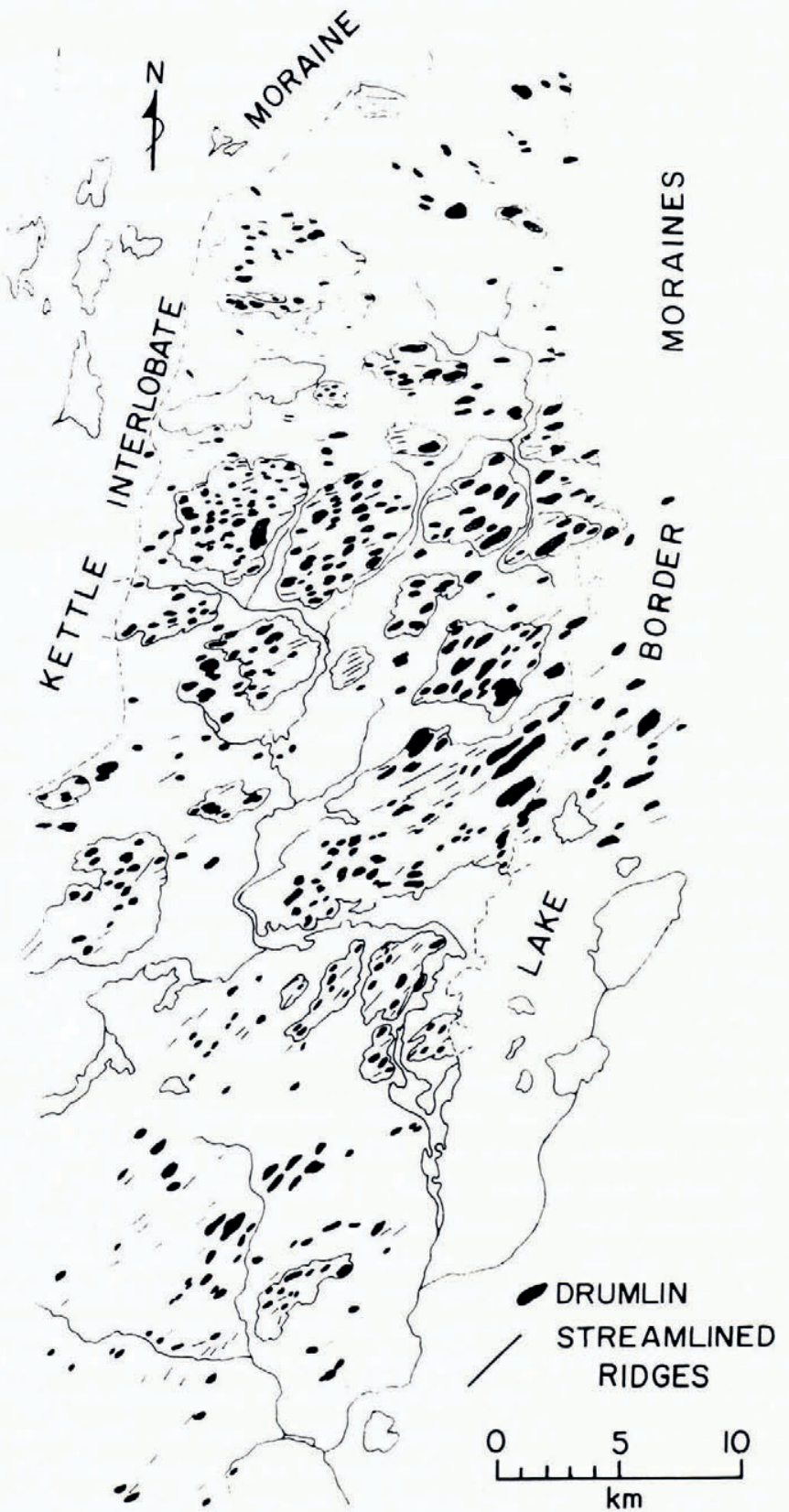

lïg. 2. Map showing drumlins, lakes, streams, mornines, and margins of drumlinized uplands. 
Darien moraine is difficult to measure because of the younger moraines which bury the eastern end of the drumlin field. The density of drumlins decreases markedly from about six drumlins per $\mathrm{km}^{2}$ nearly $50 \mathrm{~km}$ from the terminal moraine to almost no drumlins or streamlined hills at 5-10 km. This is roughly the same trend as in the neighboring Green Bay lobe, where over 5000 drumlins are present within a zone from about $15^{-80} \mathrm{~km}$ in back of the terminal moraine. The up-ice border of this large drumlin field is an abrupt break between a very drumlinized area and the smoother ground moraine to the north; the down-ice boundary is very transitional as drumlins become more widely spaced.

Like most other drumlin fields, the Waukesha drumlins have a fan-shaped pattern of streamlining, here ranging from $290^{\circ}$ to $220^{\circ}$ (Figs I and 2). No major discrepancies were found between the drumlin alignments and striations on bedrock indicating ice-flow directions; the minor differences observed could have been the result of ice flowing around the drumlins or else due to waning ice flowing according to local ice-surface slopes during deglaciation. The drumlins show no deflection or any other altered flow pattern on their western edge where the Lake Michigan and Green Bay lobes converged.

The uneven spatial distribution of drumlins throughout the Waukesha area is obvious from Figure 2. A $\chi^{2}$ test comparing the drumlins' frequency per square mile and the "random" Poisson frequency distribution produced a calculated $\chi^{2}=156.892$ and a tabled value $\chi^{2}=29.588$ (o.or confidence level) (Whittecar, unpublished). This suggests that the drumlins have either a "regular" or a "clustered" pattern (Oeppen and Ongley, 1975). The variancemean ratio of the quadrat data (1.984) is larger than unity, thereby implying that the drumlins are "clustered" (Rogers, I 974).

Not only are the drumlins clustered but they are usually grouped atop distinct uplands made of drumlinoid features. The uplands can be mapped by outlining the base of the scarp which separates one upland from another and from the broad valleys often found between the uplands. As Figure 2 illustrates, although not all drumlins are found on uplands and some rise from the broad outwash-filled valleys, the uplands dominate the landscape in the center of the drumlin field. All uplands have sets of parallel interfluves which sometimes cover the entire surface if no drumlins are present. This landscape is similar to others in North Dakota described as "scoured by a gigantic rake" (Aronow, I959, p. I95) and the "drumlin shield" in Finland (Glückert, 1971, from Embleton and King, 1975).

Miller (1972) reported that a similar clustered situation existed in parts of the Lake Ontario drumlin field in New York. He suggested that either clustering was developed by melt-water channelization removing drumlins once formed in the valleys between uplands or that thick drift might bury low-lying drumlins. However, since large fluvial erosion channels are indistinct and melt-water tributary networks are difficult to reconstruct, Miller thought also that drumlins may never have been formed in the valleys. Precisely the same features and arguments are applicable to the Waukesha area.

Drumlin boundaries are difficult and often unpractical to delineate where they are crowded together on the uplands. Even so, it is obvious that most of these drumlins do not fall into the "ideal" drumlin description (Flint, [I97I]) with marked asymmetry and oval contours. Many drumlins have diamond-shaped contours, are irregular due to bedrock influences or are nearly circular. Some drumlins do have higher length-to-width ratios of $6:$ I to $8: \mathrm{I}$, and these tend to be asymmetric with steeper slopes pointing up-ice.

Mills (unpublished) compared dimensions of drumlins in groups throughout the United States. His analysis of the Hartland and Genesee I : 24 ooo U.S.G.S. topographic quadrangles in the area of greatest drumlin density near Waukesha produced the following data: mean width, $0.21 \mathrm{~km}$; mean length, $0.4^{8} \mathrm{~km}$; mean stature, I4. I m; length-to-width ratio, 2.20; mean stoss-to-mean lee slope ratio, 1.12. Compared to other drumlins in the United States that Mills measured, these drumlins are generally shorter, of average width, and most nearly symmetric about their short axes. 


\section{COMPOSITION OF THE DRUMLIN INTERIORS}

Information about the interiors of the drumlins comes from gravel-pit exposures, road cuts and well logs. These sources of data show that most, if not all, of the drumlins are cored by gravels interbedded in places with several pre-drumlin till layers.

Sands and gravels within the drumlins are interpreted as sheets of outwash deposited in front of an ice mass; well logs suggest that these units were once continuous over broad areas. The gravel layers range from i to $10 \mathrm{~m}$ thick and contain mostly dolomite fragments with some crystalline erratics. Paleocurrent directions were determined in the sand and gravel by measuring cross-bedding and gravel imbrication. Following methods described by Rust (1975), 30 or more gravel clasts were measured at i 6 locations within eight drumlins near Waukesha. Cross-bed dip directions were gathered where available in six different gravel pits. All of the data concerning the shape, distribution, and current structures of the sand and gravel unit strongly suggest that it developed as a pro-glacial outwash plain rather than in stratified drift deposited beneath the ice (Whittecar, unpublished).

Interbedded within the outwash layers are several pre-drumlin tills. At least two tills are distinguishable from the surface till and each other by stratigraphic position, grain lithologies, and textures (Whittecar, unpublished). Angular unconformities, superposition, and till fabrics indicate that these tills were deposited by earlier ice masses unrelated to the formation of the drumlins.

\section{"AdVAnce" AND "RETREat" TILls}

The very stoney and compact sandy till above the outwash cores of the Waukesha drumlins has a wide range of textures. Even so, no significant compositional differences can be identified between any till layers exposed at or near the surface of the drumlins. The highly variable thickness of the surface till ranges from $30 \mathrm{~m}$ under the tops of some drumlins to $3 \mathrm{~m}$ thick on sides and under inter-drumlin lows. Along the slopes of especially steep drumlin uplands the till is not present, either having been eroded since deglaciation or not having been deposited at all. In most areas though, till completely blankets the landscape. Fabrics taken in this basal till generally indicate ice flow parallel to the drumlin axes (Whittecar, unpublished).

The significant sub-division to be made within the till units above the gravels is the structural distinction between till which markedly truncates all units below it and that till which is usually conformable with lower beds. Although best seen in drumlins with contorted bedding, it is possible to see these two tills within gravel- and till-cored drumlins containing flat-lying beds. The thick till cap under the center of the hill thins away from the summit to the point where it remains the same thickness over the drumlin's lower flank (Fig. 7). The gravel-till contact is horizontal and conformable to the sand and gravel layers up to a point where the contact begins to cut across the layers. However, it is in the drumlins that contain large folds that one finds the most dramatic distinction between truncated and truncating tills. Where large overturned folds or clastic dikes have brought steep-angled outwash beds close to the surface of the drumlin, it is common to see one thin till cutting across the gravel bedding, while a thicker till is conformably lying atop the folded gravels. The conformable till was probably deposited during ice advance; the truncating till was likely deposited near the margin of the retreating ice (Whittecar and Mickelson, I977).

Because of their practically identical composition, it is difficult to distinguish between the "advance" and "retreat" tills where they are in contact. It may be possible in some excellent exposures to trace a contact based on a slight difference in stoniness or vague hints of unconformable bedding and occasional sand lenses. However, in no exposure does unquestionable glaciofluvial material that could not have been a thin smearing of debris from an adjacent, truncated outwash unit lie between the two tills. 
The lack of differences between these two tills suggests they were deposited by the same glacier. Because the till conformable to the gravel bedding is involved in localized deformation and is truncated at the margin of the drumlin, it surely was deposited before or intermittently during the erosion of the drumlins. This thick till was probably deposited as the ice irregularly advanced over the outwash plain once covering the Waukesha area. We informally refer to this as "advance" till. We think that the thin "retreat" till which blankets the drumlin landscape was deposited as the ice-sheet margin retreated over the new drumlins and back into the Lake Michigan basin.

Most of the sedimentary layers exposed within the drumlins are in their original flat-lying positions. The implications of finding this largely undisturbed drift truncated by the drumlin forms are quite clear: the drumlin shapes were carved by subglacial erosion. As the Lake Michigan ice spread out of its basin. it cut the pre-existing landscape into elongated hills aligned in the direction of ice flow. Furthermore, from the hills' shapes and the pattern of drumlin distribution discussed earlier, we deduce other aspects of the ice flow and erosion.

(a) The fan-shaped pattern of drumlins in both the Waukesha area and the Green Bay lobe to the west suggests that compressive flow conditions existed in a broad zone up-ice of the margin. In compressive flow, ice spreads towards the margin of the lobe and slows down relative to the ice up-glacier. This flow regime produces ice flow away from the base of the glacier and tends to result in debris being carried higher up into the ice (Nye, 1952). Weertman $(196 \mathbf{r})$ and others predicted that geothermal flux and friction would melt water from the sole of a large ice sheet. At some point, as the melt water migrated towards the colder toe of the ice, it would refreeze to the glacier, probably incorporating large quantities of fractured or unconsolidated substrata. If these zones of regelation and compressive flow coincided, the potential for basal erosion could be very high. Such a juxtapositioning of zones would not be unlikely. Clayton and Moran ( $\left[{ }^{\mathrm{C}} \mathrm{I} 974\right]$ ), Boulton (1972), and others considered it quite possible that the Pleistocene ice advanced over the permafrost in some areas and that their margins were frozen to their beds. Such a frozen ice margin would have little or no basal sliding, thereby additionally slowing the peripheral ice and enhancing the difference in flow velocities from the center to the margins of the ice sheet.

(b) The clustering of the drumlins and streamlined ridges on distinct uplands suggest that the ice formed the drumlins on the highlands of the pre-existing landscape. Within these clusters, drumlin summits commonly are arranged in the en échelon or side-by-side pattern of three to five hills that has been described in many drumlin landscapes (e.g. Alden, 1905; Fairchild, 1907; Hollingworth, 1931; Rose and Letzer, 1977). Although this tight linear grouping may be a product of randomly distributed drumlins such as depicted by Smalley and Unwin ( 1968 , p. 384 ), the pattern is so prevalent as to suggest that certain circumstances during formation created this alignment. For example, the en échelon hills might be produced by eroding ice flowing over sets of interfluves running oblique to the flow of ice. Where this occurred, it may be possible in limited areas to estimate the land surface existing before the ice advanced.

\section{INTERNAL STRUGTURES}

A few of the 17 drumlins exposed near Waukesha show varying degrees of disturbed bedding as well as horizontal layers. Most of the features fall into a continuum of large deformation features ranging from mostly flat-lying bedding through large clastic dikes and overturned folds to highly faulted and folded structural complexes.

\section{Clastic dikes}

Clastic dikes are well exposed in two drumlins south-east of Waukesha. Figure 3 shows one clastic dike which has steeply dipping gravels warped about a wedge of highly contorted 
fine sands, silts, and till. The gravels flatten out within $30 \mathrm{~m}$ of the center of the dike. Many dikes reach to the surface of the drumlin, often forcing sands and gravels very close to the surface where they may be exposed by post-glacial erosion. Some dikes' cores are elongated bodies which trend in the same direction as all other dikes within that drumlin; other dikes' cores are more equi-dimensional in plan view and resemble domes rather than doubly plunging anticlines.

The orientation of the dikes found within the two drumlins is puzzling (Fig. 4). One drumlin has over ten dikes; two dikes are perpendicular to the ice flow, one dike is a domal feature and the rest trend parallel to the long axis of the drumlin. The other drumlin has a zone of dikes and upwarping which trends perpendicular to ice flow. Dikes parallel to the
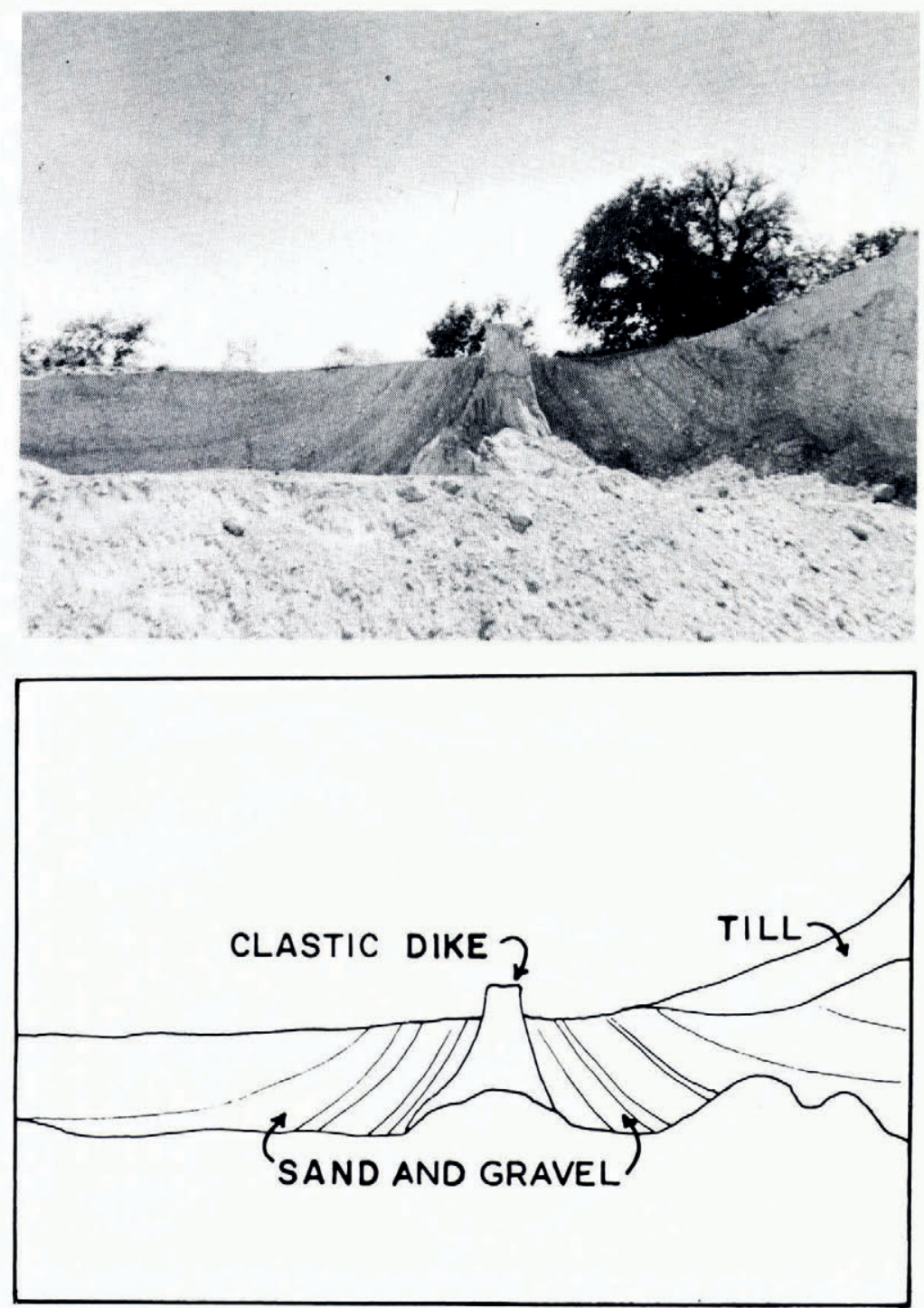

Fig. 3. Photograph and sketch of a clastic dike. The pit wall is 6 -10 $\mathrm{m}$ high. Ice flow was almost directly into the page. 
ice-flow direction might be explained by the compressive ice-flow regimes which apparently are present where drumlins are formed. In compressive flow, the maximum tensile stress is perpendicular to the ice-flow direction (Nye, 1952). As the material in the cores of the dikes moved upward, it would have penetrated the overlying gravels in directions along which the gravels were most likely to separate. If no inherent weaknesses were present in the overlying gravels, compressive flow may have induced the gravels to separate along lines parallel to ice flow. Dikes not parallel to ice flow are more difficult to explain. They may have started their
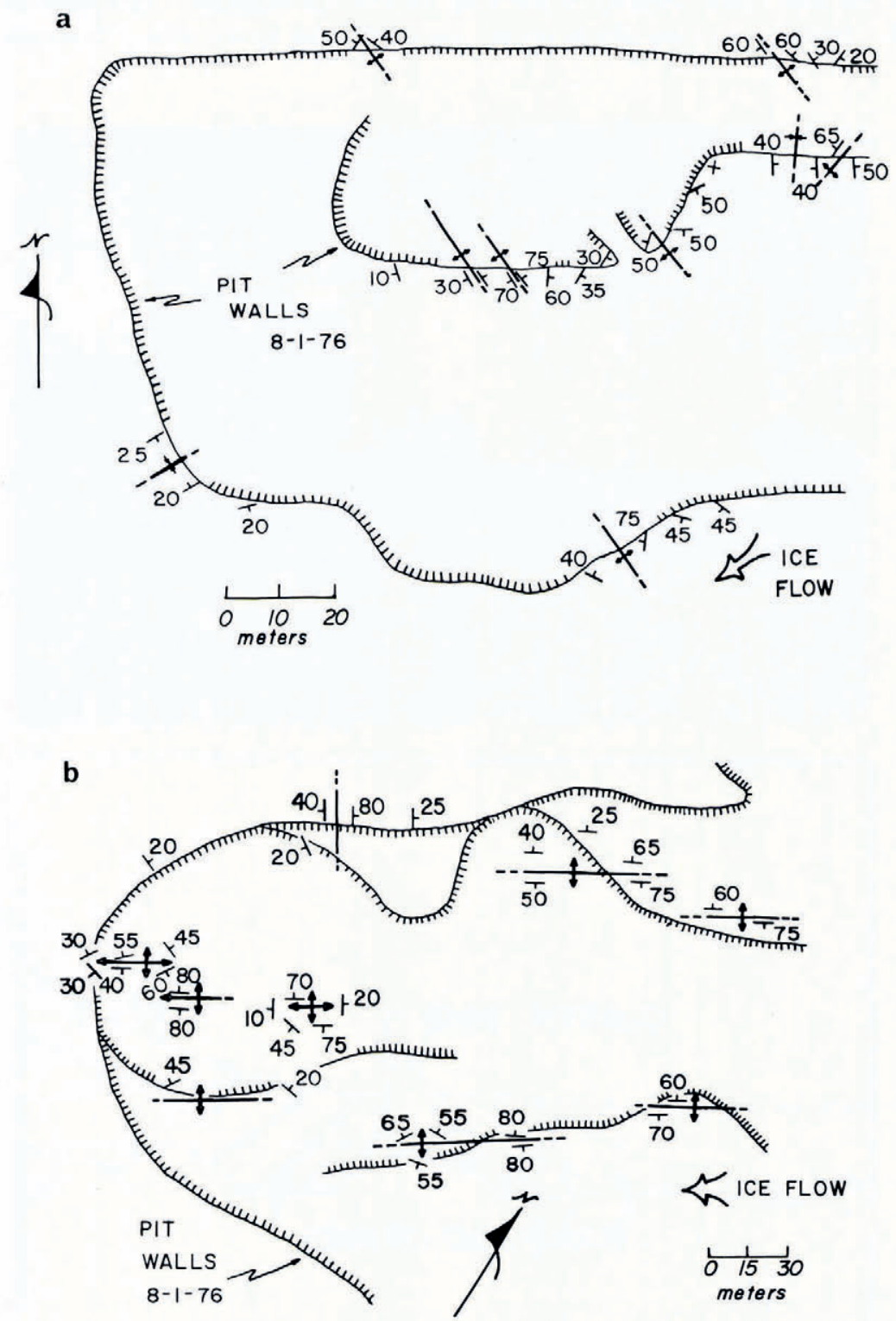

Fig. 4. Maps of parts of excavated drumlins showing clastic dikes, faulted clastic dikes, and minor folds. In Figure 4 a, the drumlin axis is roughly $30 \mathrm{~m}$ north-west of the corner of the pit; in Figure $4 b$, the drumlin axis is roughly $100 \mathrm{~m}$ north-west of the pit. 
upwelling in areas where cracks (e.g. ice wedges?) or some other weak lineation provided the easiest route for movement of the underlying material. Unfortunately, our considerations about the causes of clastic-dike orientation are highly speculative since the observations are limited to so few sites.

The presence of these clastic dikes invites a number of interpretations of subglacial conditions. For these dikes to form, the finer-grained beds under the thick outwash must have been mobilized due to some sub-ice process. Several mechanisms may have played a role in initially destabilizing the cores of the dikes. Because of changes in dilatancy caused by increased shear and loading, finer-grained materials deform more quickly than coarser deposits (Smalley and Unwin, 1968). Therefore, as ice thickened over a particular location, increased stresses may have reached a mobilizing threshold level in the fine sands, silts, and tills, while the gravels were still resisting deformation. If the sediments were saturated, other potential instabilities may have occurred either because of increased pore pressure caused by thicker ice and greater hydrostatic heads, or because of reverse density gradients caused by low-porosity gravel lying over fine-grained sediment having a higher porosity. Probably a combination of these and other factors induced the finer-grained sediment to become less stable and move upwards in the stratigraphic section.

The presence of the dikes also suggests that, once the finer-grained beds were unstable and capable of moving, differential pressures around the drumlin could have aided the movement of material up into the drumlin form. The pressures due to loading along the flanks of the hills would be slightly greater than those on the summit because of the height of the column of ice above each point. Furthermore, shear stress resulting from ice movement would be highest on the up-ice flank and side slopes of the drumlin. Earlier studies (Boulton, [ ${ }^{\mathrm{C}}$ I974], I976) have suggested that, as ice flows around an obstacle, these pressure differentials create lower stress or even cavitation on the tops and lee sides of the obstacle. Several workers have used this concept to propose that material at the base of the ice moves into zones of lower pressure (Gravenor and Menley, I958; Evenson, [ $\left.{ }^{\mathrm{c}}{ }_{197} \mathrm{I}\right]$ ). This concept also seems applicable to some of the drumlins in the Waukesha area.

\section{Folds with overturned bedding}

Folds with overturned bedding are found in five of the drumlins which have deformed bedding. Two types of these folds may be significant to drumlin formation: (I) very large folds which probably resulted from the faulting of the two limbs of a clastic dike and continued movement of one of the limbs, and (2) large S-shaped shear folds along the flanks of drumlins which have fold axes oblique to the long axis of the drumlin.

The first fold type may incorporate a sizable fraction $(10 \%+)$ of the interior of the drumlin. It was apparently started as the two limbs of a clastic dike were displaced along a high-angled fault near the dike's core. One limb was thrust upward more rapidly than the other, resulting in material low in the stratigraphic section being pushed close to the surface (Fig. 5). Within two of the Waukesha drumlins, as the detached limb moved upward along the fault, the beds nearest the surface were overturned. The mechanism of this overturning is unknown, although it is probably related to the shear stress of the ice, ice-flow direction, and the respective orientations of the fault and the active limb of the clastic dike. Furthermore, since near-vertical faults with high-angled thrusting are found in many other drumlins in the Waukesha area, it seems possible that large-scale overturned folds and thrusts might develop in drumlins without clastic dikes.

In three locations along flanks of two drumlins, normally horizontal beds were warped into large S-shaped folds with their axes oblique to the ice-flow direction. Figure 6 a pictures one such fold in glacial materials which was truncated by the till along the side of the drumlin. The orientation of these fold axes might be explained by examining the stresses developed 

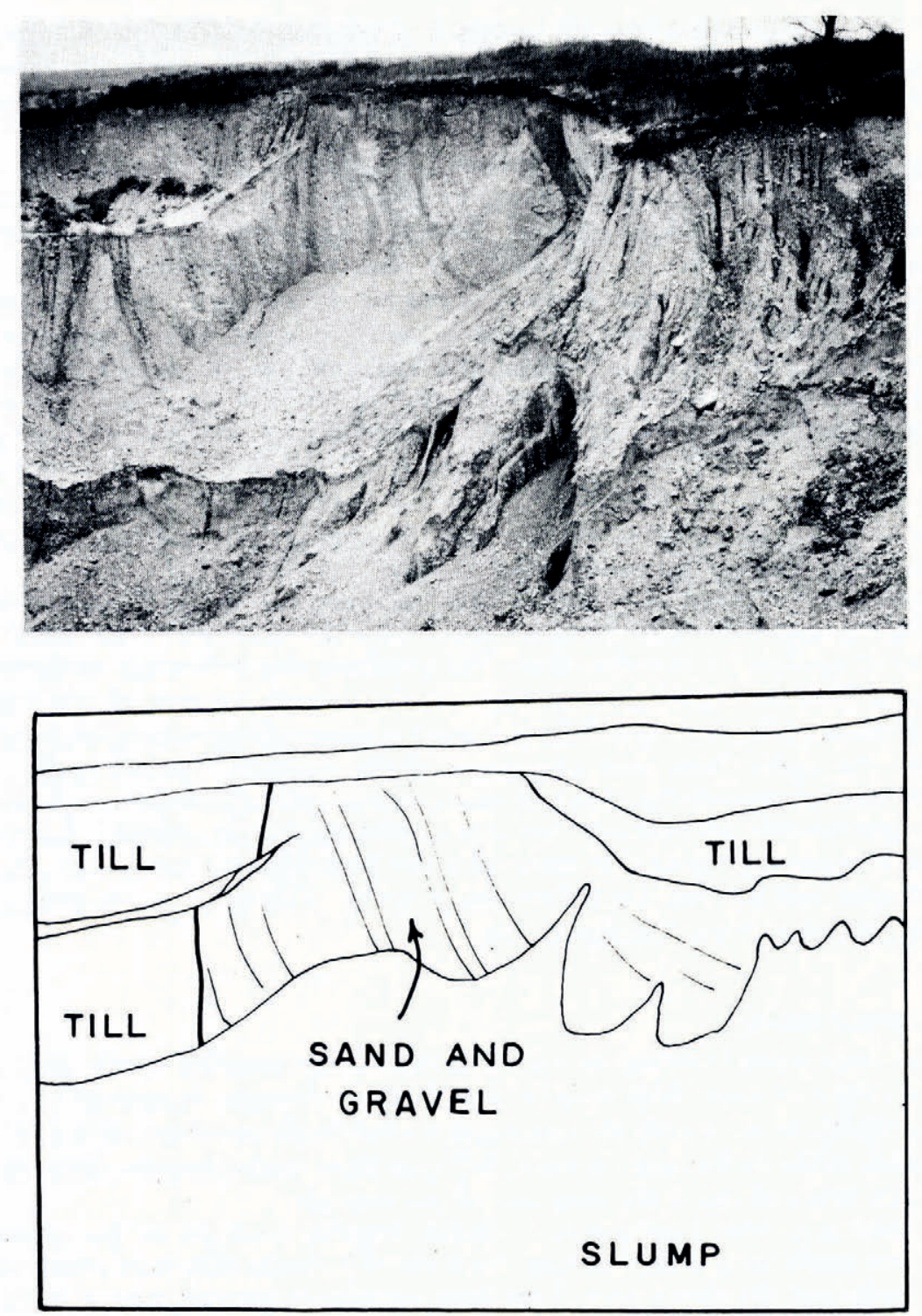

Fig. 5. Photograph and sketch of the faulted clastic dike shown in Figure $4 b .2-4 m$ of till were stripped from the top of the cut by mining operations.

along the side of a drumlin as ice flowed around it. If the shear stress of the moving ice is $\tau_{\mathrm{I}}$ and its normal stress is $\eta_{\mathrm{I}}$, the stress vectors resisting shear and normal pressures would be $\tau_{\mathrm{D}}$ and $\eta_{\mathrm{D}}$ (Fig. 6b). The resultant vectors, $\sigma_{\mathrm{I}}$, would be the sums of these stresses. The strain ellipsoid produced by these stresses shows that the fold axes at this point should be oblique to the direction of ice flow. On viewing the entire drumlin, the predicted pattern of fold axes produced in this way might be like that pictured in Figure $6 \mathrm{~b}$. The three observed folds of this style fit the pattern well. In these situations the folds seem to be the result of ice shearing past the drumlin form disturbing otherwise horizontal bedding. 

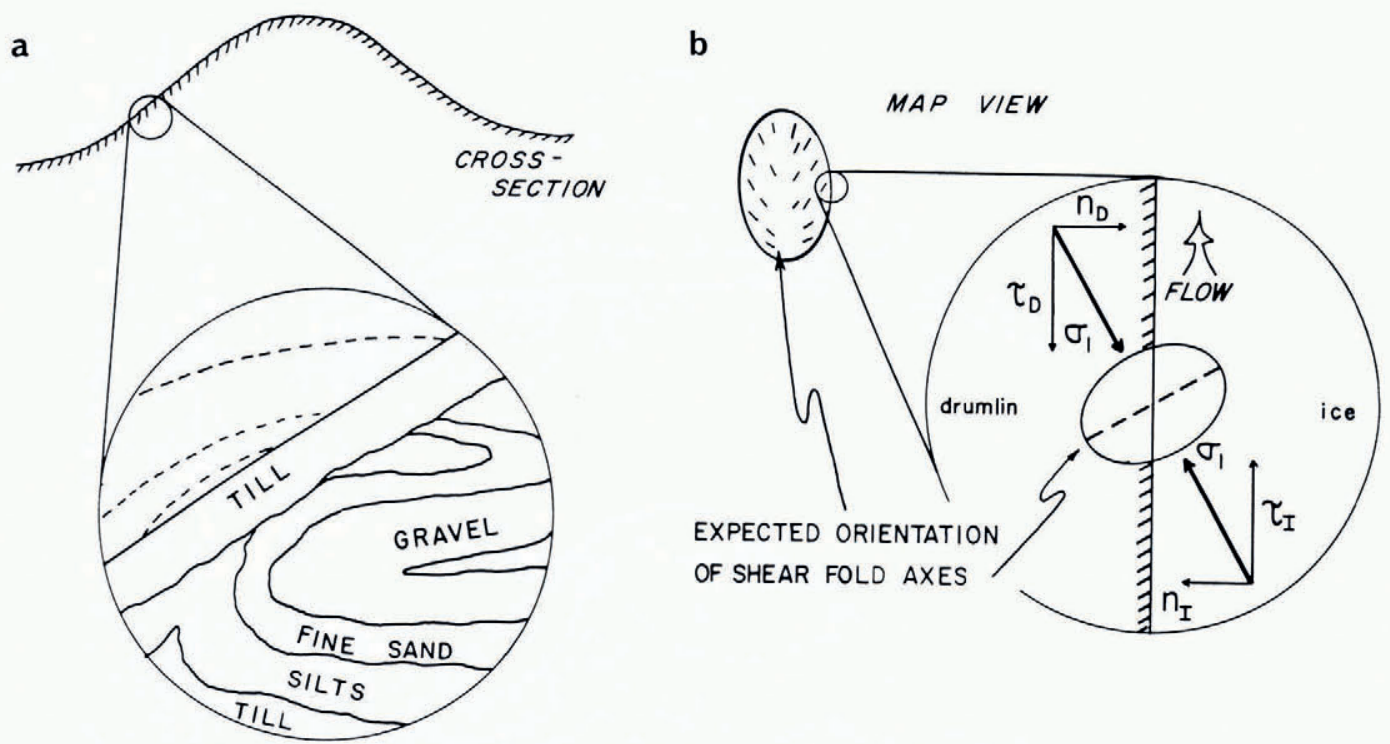

Fig. 6. (a) Cross-section sketch of one observed shear fold at the side of one drumlin. Ice flow is into the page. (b) Strain. ellipsoid showing possible stresses developed as ice flows past drumlin flank and map view of a drumlin showing potential directions of orientations of shear fold axes. $\tau_{\mathrm{I}}$ and $\tau_{\mathrm{D}}$ are shearing stresses; $\eta_{\mathrm{I}}$ and $\eta_{\mathrm{D}}$ are normal stresses. $\sigma_{1}$ is the resulting greatest principal stress (after Moody and Hill, 1956 ).

\section{Fold and fault complexes}

The final structural style observed in the Waukesha drumlin field is represented by the highly faulted and folded complex of beds found within one drumlin. Overturned folds, fault blocks seemingly isolated from their companion block, and several near-vertical faults with tens of feet of displacement were all jumbled into the one pit wall still remaining of this excavated drumlin. It appeared as though most of the material in the drumlin had undergone some movement by at least one of the mechanisms described in less complex drumlin structures. Thus, the structural form of this drumlin's interior is at the end of the range of structures including horizontal bedding and clastic dikes (Fig. 7). As in all of the drumlins observed, the internal structures of this complex drumlin were all truncated by the thin till draped over the surface of the drumlin.

\section{Conclusions}

The two basal tills referred to as "advance" and "retreat" tills can be explained as products of deposition by the ice along a marginal zone around the glacier. Combined with the zone of partial erosion and drumlin formation, the regimes under the ice are visualized as zones of differing processes resulting in till deposition, drumlin formation due to partial erosion, and an interior zone of either erosion or no erosional/depositional activity at all (Fig. 8). The boundaries between these zones could be quite distinct or very transitional, probably depending on ice-margin fluctuations, geology of the substrata, shear stresses, ice-flow velocities, basal melt water, and a host of other variables. Despite the transitional nature of some zones' boundaries, we have seen no evidence to show that till was being deposited at the same time and place that a drumlin was being shaped. Yet, from our observations and because of the work of others (e.g. Savage, unpublished), deposition during drumlin formation cannot be ruled out. 

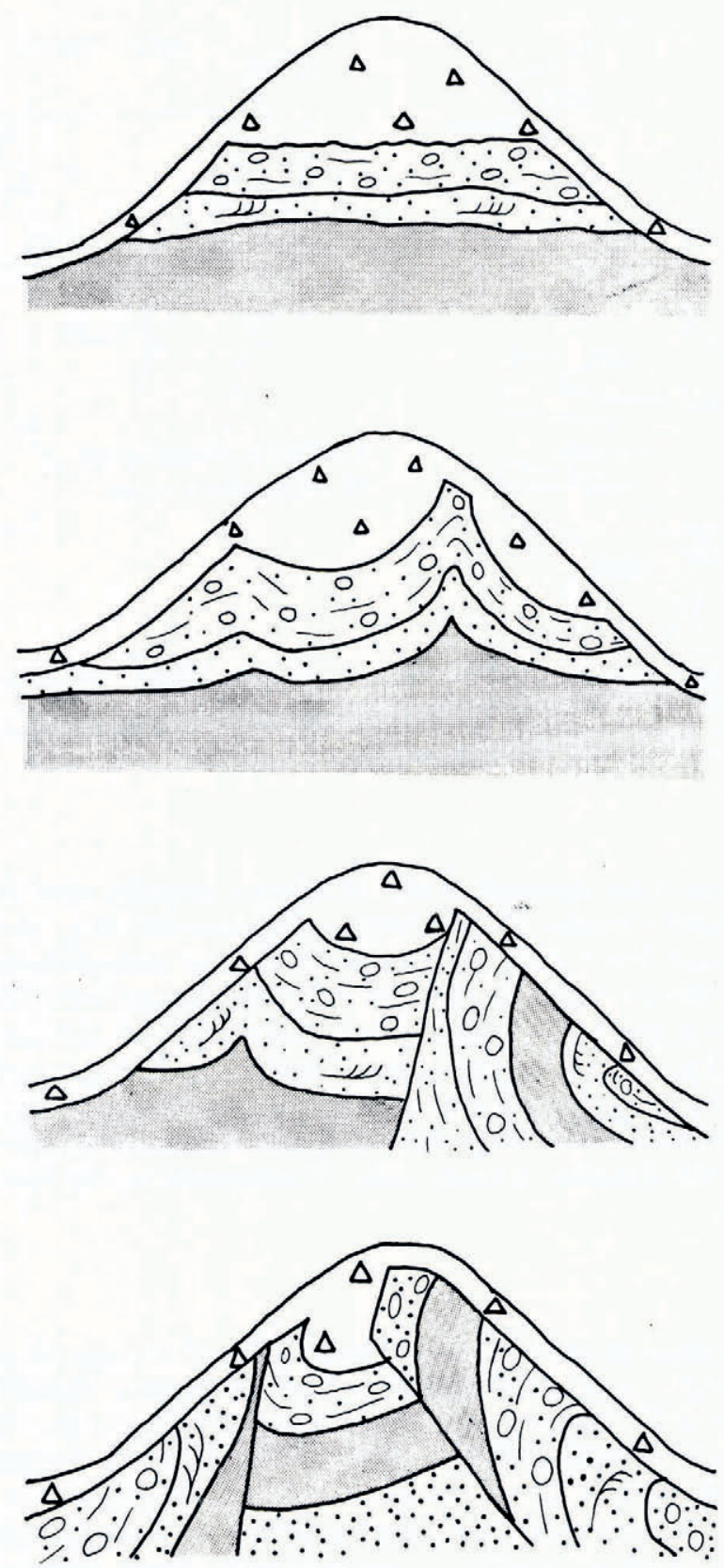

Fig. 7. Idealized range of structures found within the Waukesha-area drumlins. Included in these sketches are "advance" and "retreat" tills, clastic dikes, high-angle faults, large overturned folds, and highly complex combinations of these features. All sections are along the short axes of the drumlins. All stratigraphic symbols are diagrammatic and are only meant to represent till lying over stratified drift. 


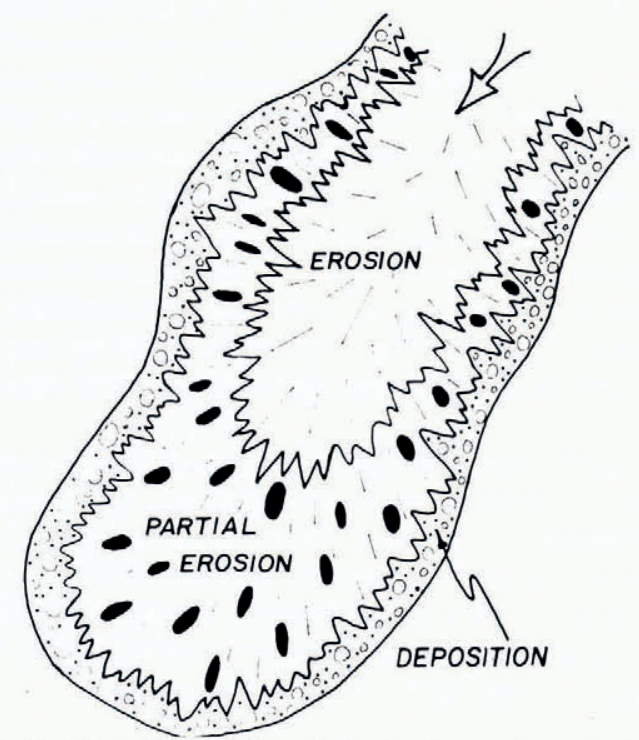

Fig. 8. Map view of the hypothesized regimes under an ice lobe.

Based upon the internal structures within the drumlins in the Waukesha area, we propose that the following sequence of events was involved in the formation of these drumlins.

I. Several advances of glacier ice and deposition of outwash and tills over incised bedrock topography.

2. Advance of ice over stream-dissected, drift-mantled topography and deposition of "advance" till in a zone near the margin of the glacier. This till is conformable with the bedding planes beneath it.

3. Continued advance and thickening of the ice. At this time the area may have been in a region of compressive flow and also in a zone of regelation of basal melt water. Erosion of the drumlin shapes.

4. Within a few drumlins there was localized folding of gravels, injection of fines as clastic dikes, faulting of some dikes, and thrusting as material was generally moved into the drumlin form from beneath. This occurred as erosion was continually removing material from the surface of the drumlin.

5. Retreat and thinning of the ice and deposition of basal till over the eroded surface. This "retreat" till was deposited near the retreating margin and is overlain in a few places by ablation till, ice-contact stratified drift, and outwash.

The individual structures exhibited in the drift in the Waukesha drumlins can be explained as elements in a range of deformation styles (Fig. 7). This series of possible structural forms begins with undisturbed horizontal bedding, continues through features showing increasing amounts of movement of material such as large clastic dikes, high-angled faults, and various styles of folds with overturned bedding. The end members of the range of features have faulted and folded complexes of disturbed subglacial debris. The particular structures described from the Waukesha drumlins may be unique results formed by special situations in ice-temperature regimes, ground-water flow, stratigraphy, and sediment bulk densities. In other drumlin fields, the detailed features of this particular sequence may be replaced by other structures. Whatever the features shown, however, they often indicate that material was being moved into the drumlin form from below. 
Undoubtedly there are many factors controlling the size and shape of drumlins, including ice-flow velocities (Chorley, I959), type of material, and thickness of the ice (Boulton, [ ${ }^{\mathrm{C}}$ I974]). We feel that the drumlin shape is primarily a product of subglacial erosion. However, we suggest that one of the factors that should be considered in the development of a drumlin's size is the relationship between the rate of erosion of the drumlin and the rate of the movement of material into the drumlin form. The two rates may be entirely independent. Yet it is conceivable that, if more material is being moved into the drumlin form than is being removed from the surface, the drumlin may grow in size. If the reverse is true and a net loss of material occurs due to relatively higher rates of glacial erosion, the drumlin should decrease in height through time. If these relationships are true, then some drumlins may owe their external shape to erosion by the ice yet the material within the drumlin may be there because of constructional activities.

Finally, the "depositional" origin of many drumlins might be attributed to the presence of a thick "advance" till that has been eroded into drumlins. Gravenor (r953) suggested a quite similar argument for "moraines of advance" being over-run by ice and eroded into drumlin forms. It might also be true that, if the over-run till was mobilized in ways similar to the drift in the Waukesha drumlin field, then any bedding or fabric in the till may be extensively deformed. In this way, a drumlin composed entirely of till layers which are identical to the surface "retreat" till might be formed by erosional processes.

\section{Aaknowledgements}

We are indebted to many people who have discussed our ideas over the years. Drs Campbell Craddock and Charles R. Bentley, University of Wisconsin-Madison, Drs William A. White and David E. Dunn, University of North Carolina-Chapel Hill, and Dr Steven R. Moran, Alberta Research Council, contributed especially valuable advice and criticism.

Field work was supported in part by the D. L. Gasser Scholarship Fund.

MS. received 30 June 1978

\section{REFERENGES}

Alden, W. C. 1905. The drumlins of southeastern Wisconsin. U.S. Geological Survey. Bulletin 273, p. 9-46.

Alden, W. C. 1918. The Quaternary geology of southeastern Wisconsin. U.S. Geological Survey. Professional Paper 106.

Aronow, S. 1959. Drumlins and related streamline features in the Warwick-Tokio area, North Dakota. American Fournal of Science, Vol. 257, No. 3, p. 191-203.

Boulton, G. S. 1972. The role of thermal régime in glacial sedimentation. Institute of British Geographers. Special Publication No. 4, p. I-19.

Boulton, G. S. [ ${ }^{1}{ }_{1974 .]}$. Processes and patterns of glacial erosion. (In Coates, D. R., ed. Glacial geomorphology. Binghamton, State University of New York, p. 4 I-87.)

Boulton, G. S. 1976. The origin of glacially fluted surfaces-observations and theory. Fournal of Glaciology, Vol. ${ }_{17}$, No. 76 , p. $287-309$.

Chorley, R. J. 1959. The shape of drumlins. Fournal of Glaciology, Vol. 3, No. 25, p. 339-44.

Clayton, L., and Moran, S. R. [' ${ }^{c}$ 1974.] A glacial process-form model. (In Coates, D. R., ed. Glacial geomorphology. Binghamton, State University of New York, p. 89-1 19.)

Embleton, C., and King, C. A. M. 1975. Glacial geomorphology. [Glacial and periglacial geomorphology. Second edition.

Vol. I.] London, Edward Arnold.
Evenson, E. B. [ ${ }^{\mathrm{c}} \mathrm{1971}$.] The relationship of macro- and micro-fabrics in till and the genesis of glacial landforms in Jefferson County, Wisconsin. (In Goldthwait, R. P., ed. Till: a symposium. [Columbus], Ohio State University Press, p. $345-64$.)

Fairchild, H. L. 1907. Drumlins of central western New York. New York State Museum Bulletin, Vol. II I, p. $3^{81-443 .}$

p. 381-443.
Flint, R. F. [1971.] Glacial and Quaternary geology. New York, John Wiley and Sons, Inc.

Glückert, G. 197I. Drumlinlandschaft auf der Wasserscheide zwischen Pieksämäki und Haukivuori in Mittelfinnland. Bulletin of the Geological Society of Finland, No. 43, Pt. 2, p. 141-6r. 
Gravenor, C. P. 1953. The origin of drumlins. American Journal of Science, Vol. 251, No. 9, p. 670-81.

Gravenor, C. P., and Menley, W. A. 1958. Glacial flutings in central and northern Alberta. American Journal of Science, Vol. 256, No. 10, p. 715-28.

Hollingworth, S. E. 1931. The glaciation of western Edenside and adjoining areas and the drumlins of Edenside and the Solway basin. Quarterly Journal of the Geological Society of London, Vol. 87, Pt. 2, p. 28I-359.

Martin, L. 1916. The physical geography of Wisconsin. Wisconsin Geological and Natural History Survey Bulletin No. 56 .

Miller, J. W., jr. 1972. Variations in New York drumlins. Annals of the Association of American Geographers, Vol. 62, No. 3 , p. $41^{8-23}$.

Mills, H. H., jr. Unpublished. The variation of drumlin form. [M.Sc. thesis, University of North CarolinaChapel Hill, 1972.]

Moody, J. D., and Hill, M. J. 1956. Wrench-fault tectonics. Bulletin of the Geological Society of America, Vol. 67, No. 9 , p. $1207-46$.

Muller, E. H. [ ${ }^{{ }_{1}}$ 974.] Origins of drumlins. (In Coates, D. R., ed. Glacial geomorphology. Binghamton, State University of New York, p. $187-204$.)

Nye, J. F. 1952. The mechanics of glacier flow. Journal of Glaciology, Vol. 2, No. 12, p. 82-93.

Oeppen, B. J., and Ongley, E. D. 1975. Spatial point processes applied to the distribution of river junctions. Geographical Analysis, Vol. 7, No. 2, p. $153-71$.

Rogers, A. 1974. Statistical analysis of spatial dispersion: the quadrat method. London, Pion Ltd.

Rose, J., and Letzer, J. M. 1977. Superimposed drumlins. Journal of Glaciology, Vol. 18, No. 80, p. 47 1-8o.

Rust, B. R. 1975. Fabric and structure in glaciofluvial gravels. Society of Economic Paleontologists and Mineralogists. Special Publication No. 23, p. 238-48.

Savage, W. Z. Unpublished. Application of plastic flow analysis to drumlin formation. [M.Sc. thesis, Syracuse University, 1968.]

Smalley, I. J., and Unwin, D. J. 1968. The formation and shape of drumlins and their distribution and orientation in drumlin fields. Journal of Glaciology, Vol. 7, No. 51, p. 377-9o.

Weertman, J. 1961. Mechanism for the formation of inner moraines found near the edge of cold ice caps and ice sheets. Journal of Glaciology, Vol. 3, No. 30, p. 965-78.

Whittecar, G. R., and Mickelson, D. M. 1977. Sequence of till deposition and erosion in drumlins. Boreas, Vol. 6, No. 2, p. 213-17.

Whittecar, G. R. Unpublished. The glacial geology of the Waukesha drumlin field, Waukesha County, Wisconsin. [M.Sc. thesis, University of Wisconsin-Madison, 1976.]

Willman, H. B., and Frye, J. C. 1970. Pleistocene stratigraphy of Illinois. Illinois Geological Survey Bulletin No. 94. 